\title{
Voltage-Dependent $\mathrm{Ca}^{2+}$-Channel Block by Openers of Intermediate and Small Conductance $\mathrm{Ca}^{2+}$-Activated $\mathrm{K}^{+}$Channels in Urinary Bladder Smooth Muscle Cells
}

\author{
Kozo Morimura ${ }^{1}$, Hisao Yamamura ${ }^{1}$, Susumu Ohya ${ }^{1}$, and Yuji Imaizumi ${ }^{1}$,* \\ ${ }^{I}$ Department of Molecular and Cellular Pharmacology, Graduate School of Pharmaceutical Sciences, \\ Nagoya City University, Nagoya 467-8603, Japan
}

Received January 5, 2006; Accepted January 27, 2006

\begin{abstract}
We examined effects of small and intermediate conductance $\mathrm{Ca}^{2+}$-activated $\mathrm{K}^{+}$(SK and IK) channel openers, DCEBIO (5,6-dichloro-1-ethyl-1,3-dihydro- $2 H$-benzimidazol-2-one) and NS309 (3-oxime-6,7-dichloro-1H-indole-2,3-dione), on L-type $\mathrm{Ca}^{2+}$ channel current $\left(\mathrm{I}_{\mathrm{Ca}}\right)$ that was measured in smooth muscle cells isolated from mouse urinary bladder under whole cell voltage-clamp. The $\mathrm{I}_{\mathrm{Ca}}$ was concentration-dependently inhibited by DCEBIO and NS309; half inhibition was obtained at 71.6 and $10.6 \mu \mathrm{M}$, respectively. The specificity of NS309 to the IK channel over the $\mathrm{Ca}^{2+}$ channel appears to be high and higher than that of DCEBIO. DCEBIO and even NS309 may, however, substantially block $\mathrm{Ca}^{2+}$ channels when used as SK channel openers.
\end{abstract}

Keywords: voltage-dependent $\mathrm{Ca}^{2+}$ channel, DCEBIO, NS309

Many cellular events are triggered by the elevation of intracellular $\mathrm{Ca}^{2+}$ concentration $\left(\left[\mathrm{Ca}^{2+}\right]_{\mathrm{i}}\right)(1)$, and $\mathrm{Ca}^{2+}$ activated $\mathrm{K}^{+}$channels $\left(\mathrm{K}_{\mathrm{Ca}}\right)$ have obligatory roles in the regulation of membrane potential or cell excitability in various types of cells (2). $\mathrm{K}_{\mathrm{Ca}}$ currents contribute to action potential repolarization and afterhyperpolarization, and they also work as one of the components responsible for a negative feedback mechanism to prevent excess increase in $\left[\mathrm{Ca}^{2+}\right]_{\mathrm{i}}$ by reducing voltagedependent $\mathrm{Ca}^{2+}$-channel (VDCC) activity via membrane hyperpolarization $(3,4)$. Agents that activate $\mathrm{K}_{\mathrm{Ca}}$ may, therefore, cover or enhance this negative feedback mechanism under some of pathophysiological conditions in excitable cells (5). In non-excitable cells, membrane hyperpolarization by $\mathrm{K}_{\mathrm{Ca}}$ opening increases the driving force for $\mathrm{Ca}^{2+}$ influx through voltageindependent $\mathrm{Ca}^{2+}$ channels and rather enhances the $\mathrm{Ca}^{2+}$ signal (6). In this context, $\mathrm{K}_{\mathrm{Ca}}$ openers may enhance cellular activities, cell proliferation or even cell death in non-excitable cells.

$\mathrm{K}_{\mathrm{Ca}}$ activity can be divided into three groups: large (BK), intermediate (IK), and small (SK) conductance

*Corresponding author. yimaizum@phar.nagoya-cu.ac.jp

Published online in J-STAGE: March 4, 2006

DOI: $10.1254 /$ jphs.SC0060011
$\mathrm{K}_{\mathrm{Ca}}$ channels. 1-EBIO (1-ethyl-2-benzimidazolinone) was found to stimulate the secretion across colon epithelium by activation of IK current and identified as an opener of cloned SK channels as well as IK channels (7, 8). DCEBIO and NS309 have been developed as IK/SK openers with higher potency and widely used as pharmacological tools (Fig. 1A: a, NS309; b, DCEBIO). These compounds possess a therapeutic potency for cystic fibrosis and chronic obstructive pulmonary disease by improving epithelial $\mathrm{Cl}^{-}$secretion via IK channel activation (9) and for moderating neuronal hyperexcitability by enhancing apamin-sensitive afterhyperpolarizing current ( $\mathrm{I}_{\mathrm{AHP}}$, mediated by SK channels) $(10,11)$. In a preliminary study, we found, however, that DCEBIO markedly reduced VDCC current in a concentration range close to that for IK/SK channel activation in urinary bladder smooth muscle cells (UBSMCs). It is likely that VDCC blocking action of $\mathrm{K}_{\mathrm{Ca}}$ openers directly reduces $\mathrm{Ca}^{2+}$ influx and masks the net $\mathrm{K}_{\mathrm{Ca}}$ opening action in native excitable cells. This study was undertaken to evaluate quantitatively the VDCC-blocking action of DCEBIO and NS309 in native UBSMCs. The results provide a line of valuable information about the specificity of IK/SK openers as pharmacological tools.

C57BL/6 mice (both male and female mice, 5-10 


\section{A a NS309}<smiles>O=C1Nc2c(ccc(Cl)c2Cl)/C1=N/O</smiles>

B a

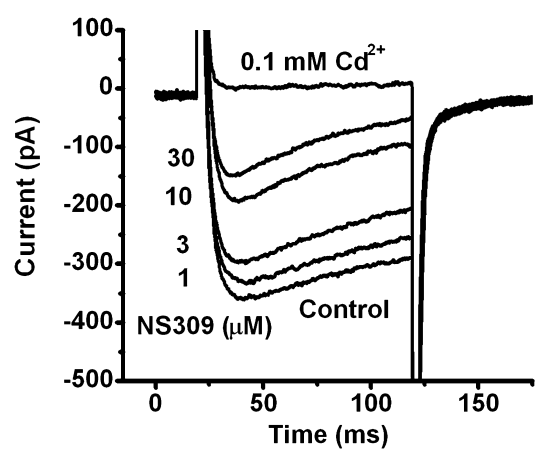

C a

NS309 ( $\mu$ M)

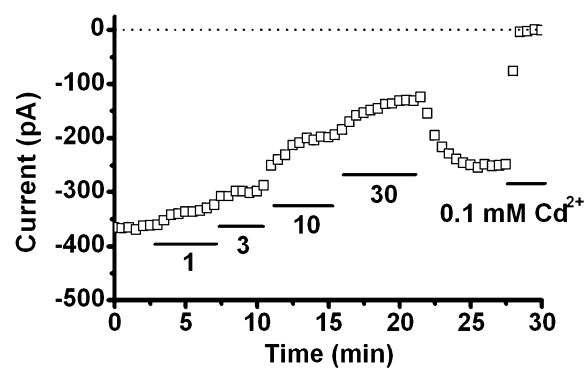

b DCEBIO<smiles>CCn1c(=O)[nH]c2cc(Cl)c(Cl)cc21</smiles>

b

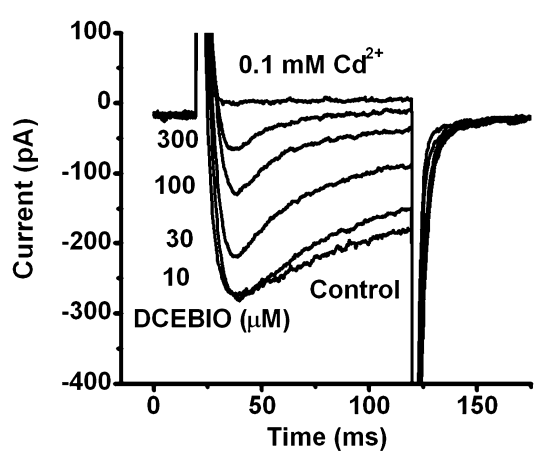

b

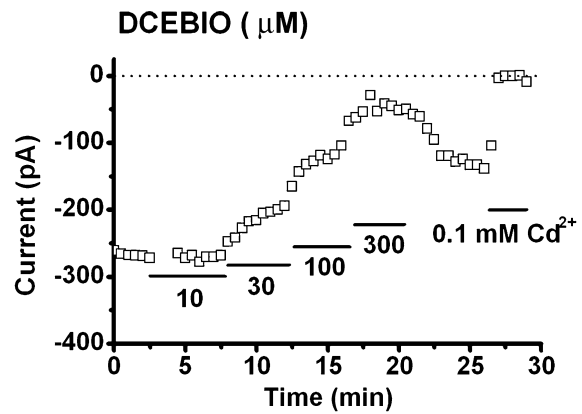

Fig. 1. Chemical structures of NS309 and DCEBIO and blocking effects on $\mathrm{I}_{\mathrm{Ca}}$ in UBSMCs. A: Chemical structures of NS309 (a) and DCEBIO (b). B: The $\mathrm{I}_{\mathrm{Ca}}$ traces obtained by depolarization from -60 to $0 \mathrm{mV}$ in the presence of $1,3,10$, and $30 \mu \mathrm{M}$ NS309 (a) and 10, 30, 100, and $300 \mu \mathrm{M}$ DCEBIO (b). $\mathrm{I}_{\mathrm{Ca}}$ was totally blocked by $0.1 \mathrm{mM} \mathrm{Cd}^{2+}$. C: Time courses of changes in peak $\mathrm{I}_{\mathrm{Ca}}$ during cumulative addition of NS309 (a) and DCEBIO (b). $\mathrm{Cd}^{2+}$ was applied at the end of each recording.

weeks of age, $20-30 \mathrm{~g}$ ) were used in the experiments. Single SMCs were enzymatically isolated using $0.1 \%$ $0.2 \%$ collagenase (Amano Enzyme, Nagoya) from the urinary bladder by previously described methods (12). All experiments were carried out in accordance with the guiding principles for the care and use of laboratory animals (the Science and International Affairs Bureau of the Japanese Ministry of Education, Culture, Sports, Science, and Technology) and also with the approval of the ethics committee at Nagoya City University.

The whole cell patch clamp techniques were applied to single cells using a CEZ-2400 amplifier (Nihon
Kohden, Tokyo) and data were stored and analyzed as described previously (12). All current records were carried out at room temperature $\left(24 \pm 1{ }^{\circ} \mathrm{C}\right)$.

The dose-response relationship for agent-induced inhibition of $\mathrm{I}_{\mathrm{Ca}}$ was determined by measuring the decrease in peak $\mathrm{I}_{\mathrm{Ca}}$ currents and fitting a curve to each set of data based on the Hill equation:

$$
\mathrm{F}=1 /\left[1+\left(\mathrm{K}_{\mathrm{d}} /[\mathrm{D}]^{\mathrm{n}}\right)\right]
$$

, where $F$ is the fractional block $\left(F=1-I_{\text {drug }} / I_{\text {control }}\right)$ at drug concentration [D], $\mathrm{K}_{\mathrm{d}}$ is the concentration producing half-maximal inhibition, and $\mathrm{n}$ is the Hill coefficient.

Pharmacological reagents were obtained from Sigma 
(St. Louis, MO, USA) except for 1-EBIO and DCEBIO (Tocris, Ellisville, MO, USA), cadmium chloride (Wako, Osaka), and EGTA and HEPES (Dojin, Kumamoto).

For electrophysiological recordings, HEPES-buffered solution having the following composition was used as an external solution: $137 \mathrm{mM} \mathrm{NaCl}, 5.9 \mathrm{mM} \mathrm{KCl}$, $2.2 \mathrm{mM} \mathrm{CaCl}_{2}, 1.2 \mathrm{mM} \mathrm{MgCl}, 14 \mathrm{mM}$ glucose, and $10 \mathrm{mM}$ HEPES. The $\mathrm{pH}$ was adjusted to 7.4 with $\mathrm{NaOH}$. A pipette solution for $\mathrm{I}_{\mathrm{Ca}}$ recording had following composition: $100 \mathrm{mM} \mathrm{CsCl}, 20 \mathrm{mM}$ TEA, $1 \mathrm{mM} \mathrm{MgCl} 2$, $10 \mathrm{mM}$ HEPES, $5 \mathrm{mM}$ EGTA, and $2 \mathrm{mM} \mathrm{Na}_{2} \mathrm{ATP}$. The $\mathrm{pH}$ of these pipette solutions was adjusted to 7.2 with $\mathrm{CsOH}$.

Pooled data are shown as the mean \pm S.E.M. in the text. Statistical significance between two or multi groups was determined by Student's $t$-test or Scheffe's test after one-way ANOVA, respectively.

Figure $1 \mathrm{~B}$ shows the $\mathrm{I}_{\mathrm{Ca}}$ evoked by depolarization from -60 to $0 \mathrm{mV}$ for $100 \mathrm{~ms}$ at 30 -s intervals in UBSMCs in the absence and presence of NS309 (panel a) or DCEBIO (panel b) at various concentrations. The $\mathrm{I}_{\mathrm{Ca}}$, which was evaluated as the $\mathrm{Cd}^{2+}$-sensitive inward current component and $2.93 \pm 0.13 \mathrm{pA}(\mathrm{n}=17)$ in the control, was also completely blocked by $1 \mu \mathrm{M}$ nifedipine, suggesting the current was through the Ltype $\mathrm{Ca}^{2+}$ channel. The blocking effects of NS309 and DCEBIO were observed in the range of $1-30$ and $10-300 \mu \mathrm{M}$, respectively, in a concentration-dependent manner. The block can be removed by washout at least in part (Fig. 1C). Figure 2 illustrates the concentrationresponse relationships for $\mathrm{I}_{\mathrm{Ca}}$ block by NS309 and DCEBIO; the $\mathrm{IC}_{50}$ S were $10.6 \pm 1.1$ and $71.6 \pm 11.1 \mu \mathrm{M}$ ( $\mathrm{n}=5$ and $5, P<0.01)$, respectively. The Hill coefficient was $0.75 \pm 0.05$ and $1.48 \pm 0.17$, respectively $(P<0.01)$. The relatively high Hill coefficient of DCEBIO could indicate a cooperative interaction as well as hIK and SK2 activation by DCEBIO; Hill coefficients for hIK and hSK2 activation are 1.8 and 1.4 , respectively $(9,10)$. Figure $3 \mathrm{~A}$ denotes current-voltage relationships of $\mathrm{I}_{\mathrm{Ca}}$ in the absence and presence of $10 \mu \mathrm{M}$ NS309 (panel a) or $30 \mu \mathrm{M}$ DCEBIO (panel b). The peak amplitude of $\mathrm{I}_{\mathrm{Ca}} \mathrm{S}$ was measured upon depolarization and was plotted against the test potentials. The maximum $\mathrm{I}_{\mathrm{Ca}}$ was obtained at $0 \mathrm{mV}$ and reduced by $42.6 \%$ and $46.9 \%$ in the presence of $10 \mu \mathrm{M}$ NS309 and $30 \mu \mathrm{M}$ DCEBIO, respectively. Figure $3 \mathrm{~B}$ indicates the relative blockade by openers at test potentials in a range of -30 and $+40 \mathrm{mV}$. The blockade by DCEBIO was not voltagedependent but that by NS309 showed significantly smaller block at $-30 \mathrm{mV}$. Both NS309 and DCEBIO apparently increased the rate of $\mathrm{I}_{\mathrm{Ca}}$ inactivation during depolarization and slowed the deactivation following repolarization (Fig. 3: C and D).

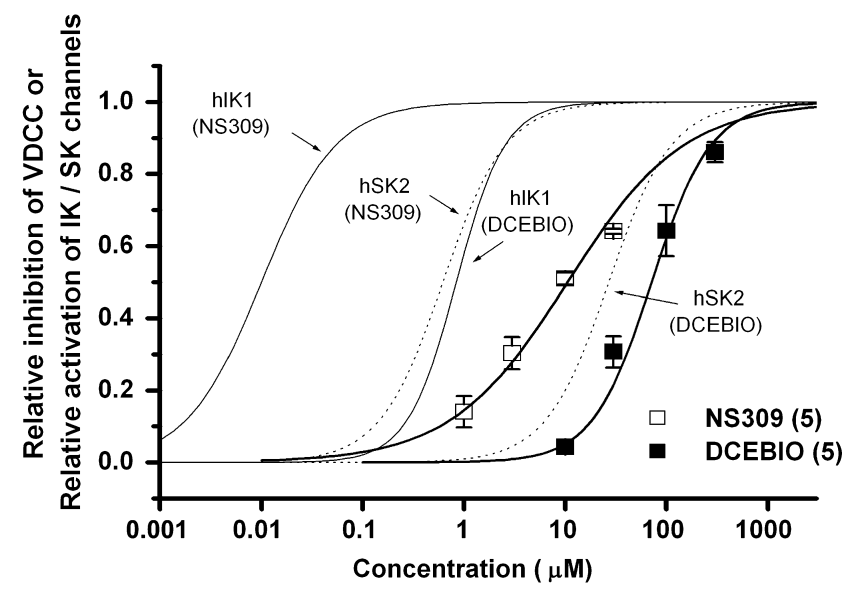

Fig. 2. The concentration-response curves of NS309 and DCEBIO for the inhibition of $\mathrm{I}_{\mathrm{Ca}}$ and the activation of IK and SK channel currents. The data of $\mathrm{I}_{\mathrm{Ca}}$ block was obtained from experiments typically shown in Fig. 1, B and C. Note that the $\mathrm{I}_{\mathrm{Ca}}$ blocking action of NS309 (open squares, $n=5$ ) was more potent than that of DCEBIO (closed squares, $n=5$ ). The data were shown as means and S.E.M. as vertical bars. The $\mathrm{IC}_{50} \mathrm{~S}$ of NS309 and DCEBIO were of $10.6 \pm 1.1$ and $71.6 \pm 11.1 \mu \mathrm{M}$, respectively $(P<0.01)$. The Hill coefficients of NS309 and DCEBIO were $0.75 \pm 0.05$ and $1.48 \pm 0.17$, respectively $(P<0.01)$. The lines indicated by hIK (NS309) and hIK (DCEBIO) were reproduced from the results published by Strobaek et al. (10) and by Singh et al. (9) in cell lines expressing cloned human IK, respectively. The $\mathrm{EC}_{50} \mathrm{~S}$ of NS309 and DCEBIO were 0.01 and $0.84 \mu \mathrm{M}$, respectively. Hill coefficients were 1.18 and 1.8 , respectively. The dotted lines that indicate the data for hSK2 (NS309) and hSK2 (DCEBIO) were reproduced from Pedarzani et al. (11). The $\mathrm{EC}_{50} \mathrm{~S}$ of NS309 and DCEBIO were 0.62 and $27 \mu \mathrm{M}$, respectively. Hill coefficients were both 1.4.

$\mathrm{K}_{\mathrm{Ca}}$ activity can be divided into three groups: large (BK), intermediate (IK), and small (SK) conductance $\mathrm{K}_{\mathrm{Ca}}$ channels. $\mathrm{BK}$ and $\mathrm{SK}$ are distributed in various types of excitable cells. In contrast, IK is mainly expressed in non-exciatble cells such as immune cells (13) but also in UBSMCs (14). Among these $\mathrm{K}_{\mathrm{Ca}}$ channels, the IK channel encoded by KCNN4 has relatively high protein homology (approximately 40\%) to three types of SK channels (KCNN1-3) and all of them are constitutively accompanied by calmodulin as a $\mathrm{Ca}^{2+}$-sensor molecule. Although SK and IK channels also share some fundamental properties, the specificity of openers, 1-EBIO, DCEBIO, and NS309, which has been determined in an expression system of cloned channels, indicates higher specificity to IK over SK by $30-60$-fold $(9-11)$. In Fig. 2, the reported results about concentration-response relationships of DCEBIO and NS309 for IK and SK2 channel opening were reproduced, together with those for $\mathrm{I}_{\mathrm{Ca}}$ blocking effects obtained in this study. The ratio between the $\mathrm{EC}_{50}$ of DCEBIO for IK opening and its $\mathrm{IC}_{50}$ for VDCC blocking was 85 and that of NS309 was 1055, indicating that both of these openers, 
A a

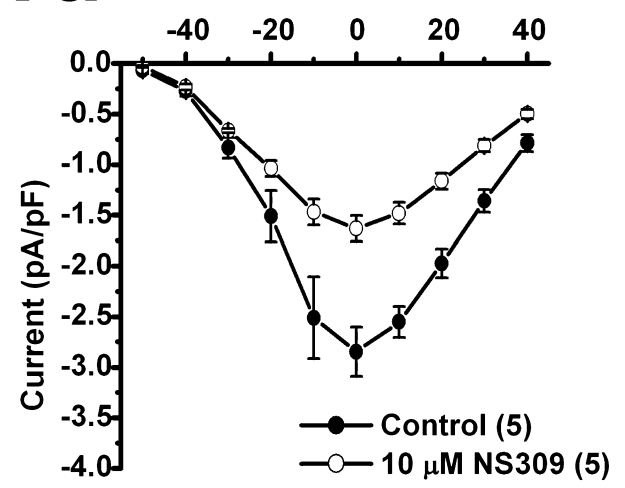

B a
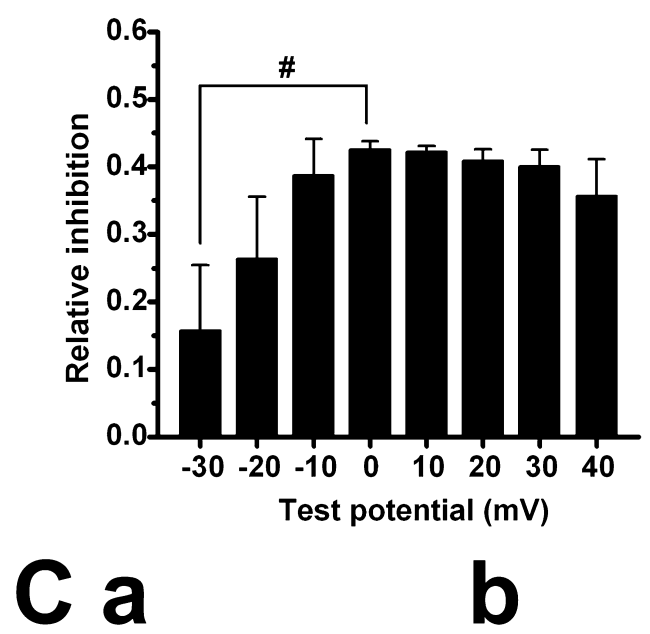

b

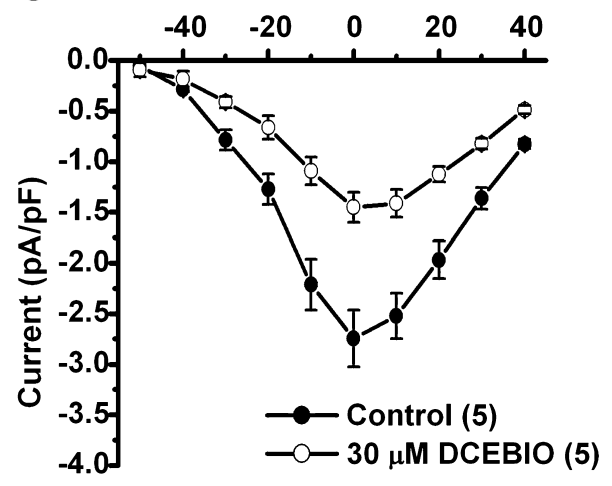

b

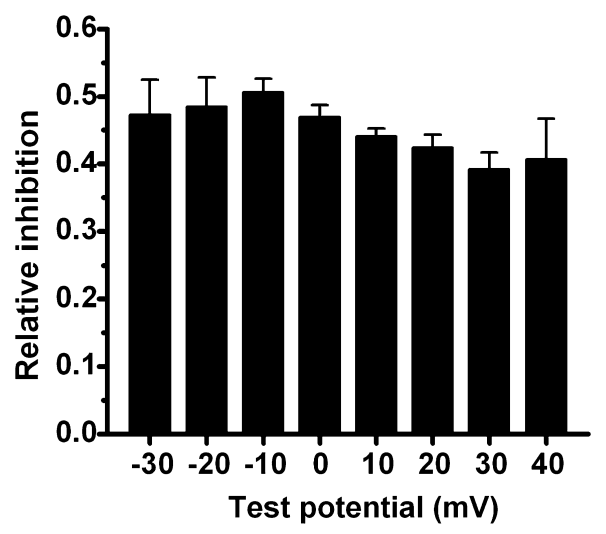

D

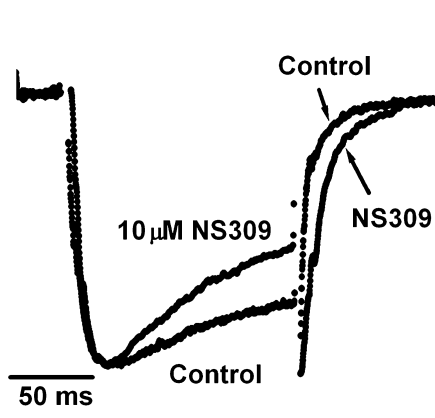

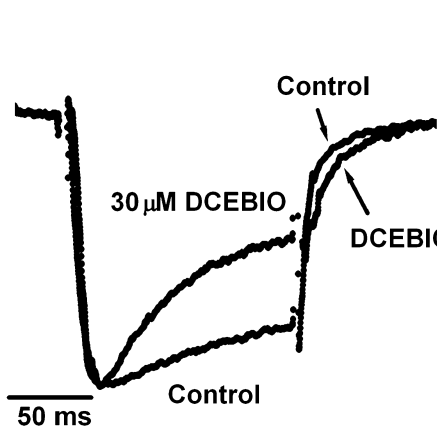

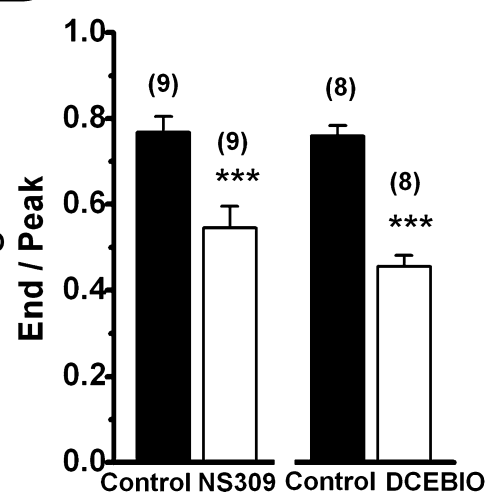

Fig. 3. Characteristics of $\mathrm{I}_{\mathrm{Ca}}$ block by NS309 and DCEBIO. A: The current-voltage relationships of $\mathrm{I}_{\mathrm{Ca}}$ were obtained in the absence and presence of $10 \mu \mathrm{M}$ NS309 (a) or $30 \mu \mathrm{M}$ DCEBIO (b). Cells were depolarized from -60 to test potentials from -60 to potentials in a range of -50 and $+40 \mathrm{mV}$ by $10-\mathrm{mV}$ steps. The numbers of cells used were five for each. The $\mathrm{I}_{\mathrm{Ca}}$ density was obtained by dividing the peak amplitude of $\mathrm{I}_{\mathrm{Ca}}$ with cell capacitance $(73.0 \pm 4.1 \mathrm{pF}, \mathrm{n}=10)$. B: The voltage-dependence of $\mathrm{I}_{\mathrm{Ca}}$ block was examined by calculating the relative inhibition of $\mathrm{I}_{\mathrm{Ca}}$ at each test potential. The relative inhibition was obtained by dividing the peak $\mathrm{I}_{\mathrm{Ca}}$ amplitude in the presence of NS309 (a) or DCEBIO (b) with that before application. ${ }^{\#} P<0.05$ between two groups. C: The effects of $10 \mu \mathrm{M}$ NS309 (a) and $30 \mu \mathrm{M}$ DCEBIO (b) on $\mathrm{I}_{\mathrm{Ca}}$ shape were shown by peak-matched $\mathrm{I}_{\mathrm{Ca}}$ traces. Capacitive transients were removed by subtraction on the computer. Note that the block of $\mathrm{I}_{\mathrm{Ca}}$ by NS309 and DCEBIO increased during depolarization. The $\mathrm{I}_{\mathrm{Ca}}$ deactivation following repolarization was slowed down by openers. D: Summarized results about effects of openers on $\mathrm{I}_{\mathrm{Ca}}$ shape were obtained from results typically shown in "C". The $\mathrm{I}_{\mathrm{Ca}}$ amplitude at the end of 100-ms depolarization was divided by that at the peak in each trace. The numbers of cells used were 9 and 8 for $10 \mu \mathrm{M}$ NS309 and $30 \mu \mathrm{M}$ DCEBIO, respectively. $* * * P<0.001$ vs control. 
but particularly NS309, is highly selective for the IK channel over VDCC. In contrast, the ratio between $\mathrm{EC}_{50}$ of DCEBIO for the SK2 channel and $\mathrm{IC}_{50}$ for VDCC was only 2.7 and even that of NS309 was 17 . In addition, it has been pointed out that DCEBIO and NS309 activate SK2 channels in a $\mathrm{Ca}^{2+}$-dependent manner (11). Therefore, SK channel activation of these drugs may be attenuated by coincidental VDCC inhibition in UBSMCs, where VDCC and SK3 channels coexist (15); and the selectivity ratio for SK channel activation and VDCC inhibition would be reduced in UBSMC.

In conclusion, both NS309 and DCEBIO show substantial block of L-type VDCC and the potency of NS309 for VDCC block is 7 times higher than that of DCEBIO. However, the specificity of NS309 for the IK channel over VDCC was much higher than that of DCEBIO. It is notable that DCEBIO and even NS309 may block, at least in part, VDCC when they are used to activate SK2 channels as pharmacological tools.

\section{Acknowledgments}

This work was supported by a Grant-in-Aid for Scientific Research (B) from Japan Society for the Promotion of Science and also by a Grant-in-Aid for Research on Health Sciences focusing on Drug Innovation from Japan Health Sciences Foundation (to Y. Imaizumi).

\section{References}

1 Clapham DE. Calcium signaling. Cell. 1995;80:259-268.

2 Vergara C, Latorre R, Marrion NV, Adelman JP. Calcium-activated potassium channels. Curr Opin Neurobiol. 1998;8:321329.

3 Stocker M, Hirzel K, D'Hoedt D, Pedarzani P. Matching molecules to function: neuronal $\mathrm{Ca}^{2+}$-activated $\mathrm{K}^{+}$channels and afterhyperpolarizations. Toxicon. 2004;43:933-949.

4 Imaizumi Y, Torii Y, Ohi Y, Nagano N, Atsuki K, Yamamura H, et al. $\mathrm{Ca}^{2+}$ images and $\mathrm{K}^{+}$current during depolarization in smooth muscle cells of the guinea-pig vas deferens and urinary bladder. J Physiol. 1998;510;705-719.

5 Lawson $\mathrm{K}$. Is there a role for potassium channel openers in neuronal ion channel disorders? Expert Opin Investig Drugs. 2000;9:2269-2280.

6 Jensen BS, Hertz M, Christopher's P, Madsen LS. The $\mathrm{Ca}^{2+}-$ activated $\mathrm{K}^{+}$channel of intermediate conductance: a possible target for immune suppression. Expert Opin Ther Targets. 2002;6:623-636.

7 Devor DC, Singh AK, Frizzell RA, Bridges RJ. Modulation of $\mathrm{Cl}^{-}$secretion by benzimidazolones. I. Direct activation of a $\mathrm{Ca}^{2+}$ dependent $\mathrm{K}^{+}$channel. Am J Physiol. 1996;271:L775-L784.

8 Syme CA, Gerlach AC, Singh AK, Devor DC. Pharmacological activation of cloned intermediate- and small-conductance $\mathrm{Ca}^{2+}$ activated $\mathrm{K}^{+}$channels. Am J Physiol Cell Physiol. 2000;278: C570-C581.

9 Singh S, Syme CA, Singh AK, Devor DC, Bridges RJ. Benzimidazolone activators of chloride secretion: potential therapeutics for cystic fibrosis and chronic obstructive pulmonary disease. J Pharmacol Exp Ther. 2001;296:600-611.

10 Strobaek D, Teuber L, Jorgensen TD, Ahring PK, Kjaer K, Hansen RS, et al. Activation of human IK and SK $\mathrm{Ca}^{2+}$-activated $\mathrm{K}^{+}$channels by NS309 (6,7-dichloro-1H-indole-2,3-dione 3oxime). Biochim Biophys Acta. 2004;1665:1-5.

11 Pedarzani P, McCutcheon JE, Rogge G, Jensen,BS, Christophersen P, Hougaard C, et al. Specific enhancement of SK channel activity selectively potentiates the afterhyperpolarizing current $\mathrm{I}_{\mathrm{AHP}}$ and modulates the firing properties of hippocampal pyramidal neurons. J Biol Chem. 2005;280:4140441411.

12 Morimura K, Ohi Y, Yamamura H, Ohya S, Muraki K, Imaizumi Y. Two-step $\mathrm{Ca}^{2+}$ intracellular release underlies excitation-contraction coupling in mouse urinary bladder myocytes. Am J Physiol Cell Physiol. 2006;290:C388-C403.

13 Grissmer S, Nguyen AN, Cahalan MD. Calcium-activated potassium channels in resting and activated human $\mathrm{T}$ lymphocytes. Expression levels, calcium dependence, ion selectivity, and pharmacology. J Gen Physiol. 1993;102:601-630.

14 Ohya S, Kimura S, Kitsukawa M, Muraki K, Watanabe M, Imaizumi Y. SK4 encodes intermediate conductance $\mathrm{Ca}^{2+}$ activated $\mathrm{K}^{+}$channels in mouse urinary bladder smooth muscle cells. Jpn J Pharmacol. 2000;84:97-100.

15 Herrera GM, Pozo MJ, Zvara P, Petkov GV, Bond CT, Adelman $\mathrm{JP}$, et al. Urinary bladder instability induced by selective suppression of the murine small conductance calcium-activated potassium (SK3) channel. J Physiol. 2003;551:893-903. 